\title{
Assessment of Modern Global Trends in Digital Trade and Finance
}

\author{
Tatiana Ignatova ${ }^{1, *}$ Christos Alexakis ${ }^{2}$ Daria Ivanova ${ }^{1}$ Egor Dudukalov ${ }^{1}$
}

\author{
${ }^{1}$ Russian Presidential Academy of National Economy and Public Administration, South-Russian Institute of \\ management, Rostov-na-Donu, 344002, Russia \\ ${ }^{2}$ ESC Rennes School of Business, Rennes, 35700, France \\ *Corresponding author. Email: tignatova1965@gmail.com
}

\begin{abstract}
The article describes the main directions of development of the digital economy through comparison of different countries. The authors argue that modern transformation processes in the international trade and finance system are aimed at ensuring its full digitalization and use of the IT in every branch of national economy. The authors conclude that the digitalization of the economy in the future will be a key institutional tool for improving the quality of production and living standards of the population.
\end{abstract}

Keywords: global trade, global finance, digital economy, world economy, globalization, transformation, IT

\section{INTRODUCTION}

The transformational changes in the international economy are going through the last 15 years quite quickly. For example, as of June 1 2017, there were 3.9 billion Internet users in the world; as of January 1, 2018, this figure reached 4, 021 billion people and is constantly increasing.

A greater number of Internet users is in Asia, but according to the specific weight from the use of the Internet the population of this region in the penultimate place. The leader in the share is North America, where the influence of transformation processes in the economy in the direction of digital development is the largest. A large proportion of Internet users and other results of the transformation of the digital economy are in the USA, the EU and Japan. On average, about $81 \%$ of the population uses new technologies. In developing countries, this figure is 2 times less. In the CIS and Eastern Europe, the share of Internet users is not more than $15 \%$. The largest number of Internet users is in China - 772 million people. Of these 753 million people use mobile banking services [1].

Economic transformation at the present stage of international development pursues the development of the digital economy, built on the change of forms and methods of providing multiple high-tech services. In General the digital economy is a set of related industries presented as a result of the introduction of new technologies. Statistics show that the share of the new digital economy in narrow sectors accounts for about $5 \%$ of gross domestic product, and the entire digital economy - more than $22 \%$ of world gross domestic product.

It is believed that the digital transformation of the economy is most exposed to the USA and China. In the USA economic system, about $1 / 3$ of gross domestic product is affected by digital transformation, making the entire financial sector fully digital in the world.

All these data underline the actuality and necessity of comprehensive research of different issues of digitalization and determine the authors' attitude to reach the research goal of classifying the main directions of digitalization.

\section{METHODOLOGY}

The opportunities provided by digital technology for the transformation of the state in the international system is unprecedented [2]. The introduction of digital technologies is blurring geographical and physical boundaries and opening up new prospects for the economic, social and cultural development of the country, as well as for the growth of regional and global competitiveness [3]. Globally, cross-border data flows increased 45-fold between 2005 and 2014, reaching \$ 2.8 trillion [4]. The impact of this process on world gross domestic product growth was higher than the impact of world trade in goods.the middle of the 20th century the most known theoretical constructions, reflected a role of scientific and technical progress in life of society, concepts of postindustrial economy (D. Bell, E. Toffler, A. Touraine, etc.), information economy (F. Makhlup, T. Umesao, M. Kastels, V.A. Trapeznikov, etc.), economies of knowledge (P. Druker, M. Porter, etc.), service economy acted (V.R. Fuchs, Zh. Attali, etc.).

Our analysis is based on the hypothesis that "Digital economy" is a type of economic activity in which the key factor of production is data in digital form, processing of large volumes of information and the use of the digital tools that in comparison with traditional forms of management can significantly improve the efficiency of various types of production, technologies, equipment, storage, sale, delivery of goods and services. The most 
important such tools became for financial markets [5]. Let's highlight the main digitalization features that differ it from traditional economy:

markets, awareness of the needs of the individual consumer, building innovative business models, rapid response to changing business conditions.

- Digital industrial cooperation (simplification of the search for cooperative ties, import substitution, creation of highly efficient value chains, optimal capacity utilization, integration of small and medium businesses in the value chain)

- Transfer of digital technologies (timely and effective stimulation of innovative activity, creation of channels of mutually beneficial exchange of innovations)

- Digital transport corridors (effective supply chain management, reduction of transportation time and associated costs, improvement of logistics systems efficiency, development of new transportation routes).

\section{CONCLUSIONS}

\subsection{First trend: Digitalization of international finance}

The use of electronic payments and various payments between banks are striking examples of the use of transformational results of the economy in the financial field. Thus, the SWIFT system, which has more than 9,000 credit institutions, from 200 countries of the world is carried out every year more than 2.5 billion payments. Payment system TARGET2 integrates between the flows of information of all States members of the EU, which allows multiple online payments.

Transformational changes in the digital economy have led to the ever-increasing role of Bank card transactions. The total number of cards as of mid-2018 reached 13.7 billion pieces. New technologies are cryptocurrencies, digital banking services are developing. Through the use of ebanking tools, commercial banks can:

1. Provide customers with statements according to the operations.

2. Inform customers on each type of banking product.

3. Receive special applications for opening new deposits, loans or Bank cards.

4. Make multiple calculations in accordance with the internal transfers for each Bank account.

5. Engaged in transfers of funds to accounts that are opened in other banking institutions.

6 . Engaged in currency conversion.

All the transformational changes in the digital economy show that the degree of involvement of users and States in Internet banking is increasing. For example, in the USA of the 100 largest banks more than 90 are engaged in the provision of various Internet services. Taking into account the development of Russia in this direction, it should be noted that the level of involvement of the population in these services can be compared with the countries of Eastern Europe [6].

The development of the financial sector allows to make changes and operations not only with the help of Internet banking, but also provides opportunities for the use of online services in the field of insurance. On many websites of insurance companies it is possible to obtain information about the services provided.

The situation is that not every insurance company still has such services in real time. However, the share of policy sales via the Internet is constantly increasing. More than $20 \%$ of all insurance product sales in the USA are online. In Russia, the use of Internet insurance is in slow development. According to the Union of insurers of the Russian Federation, in the first quarter of 2018, the total share of online fees was only $1.3 \%$. More than $85 \%$ of Russian insurance companies provide their services on the Internet. A large proportion of sales come from insurance policies, insurance property, insurance against accidents [7].

Another important result of use of the digital industry in international finance is the expansion of Internet trading, there are new electronic platforms on the stock exchange market. "Causality" tests provide a statistical framework of testing the extent of possible links among equity indices. In addition, we examine the degree of autocorrelation of the indices in order to examine the speed of adjustment to news. Our results indicated that the degree of autocorrelation is close to zero giving support that the Moscow Exchange is an efficient market in the weak form. The results of the Granger "causalities" indicated that there are no "causalities" between the examined indices supporting again the view that the Moscow Exchange is an efficient market [8]. The largest venues are the American BATS and London Chi-X Europe.

\subsection{Second trend: Digitalization of international trade and services}

Another main direction of development of the digital economy is the development of e-Commerce in the field of retail trade. The Asia-Pacific region is the leader of the market of transformational changes in this direction. European countries are in second place in terms of the use of e - Commerce elements, and North America is in third place. It should be noted that the leader is China, the market share in this direction is more than 650 billion dollars, then the USA - 340 billion dollars, and Japan - 79 billion dollars [4].

Amazon is an example of success in the development of eCommerce. The capitalization of this company over the past 3 years has become more than the market value of the world-famous investment Bank J.P. Morgan. The second most important store on the Internet is eBay, which costs \$ 10 billion [9].

Therefore consumers of services in various fields often use the Internet to order clothes, food, goods of different 
directions. The economy of participation is actively developing, which is already part of the largest transformational changes in the world.

The next important area of development of the digital transformation economy is the sphere of production, which employs not only ordinary it companies, but also those organizations that try to interact with the financial and technical sector [10]. So, in modern conditions, when Tesla from Silicon valley has spent billions of dollars to develop innovative cars, and the major giants of the automotive industry, such as Ford, Mercedes and BMW have completely revised its internal policy, and focused on the production of electric vehicles, the development of autopilot on wheeled transport and the integration of all vehicle control systems with other gadgets [11].

The fourth important direction of development of the digital economy as a result of transformational changes is the use of it technologies in the field of social sphere [12]. The leader in the development of distance education is the United States, having together with Canada more than half of the world market of e-education. The largest growth in this area is in Asia. In India - 55\%, China - more than $50 \%$, Malaysia - more than $40 \%$.

Development of rolling of things and the market of secondary sales on the Internet can really lead to decrease in demand for new expensive consumer goods from the middle class in the conditions of instability of economy. However, according to us. growth of needs of constantly increasing population of the countries with the developing economies, increase in the standard of living in the countries (India, China, etc.) plays with the multimillion population as a guarantee of increase in demand and production of cars in a mass segment in the near future. Besides, the economy of joint consumption leads to employment growth, including, secondary, in a type of the fact that the new hi-tech firms in the field of ICT aimed at an invention and implementation of new technological accessors to sharing services develop. The American researchers T. Dillahant and A. Malone paid attention to it, proving practice of expansion of employment in digital economy [13].

Digitalization of the economy as an important element of the modern international economic transformation can be a key institutional basis for the qualitative improvement of human capital, innovative thinking, production and living standards of the population in the future [14]. Each branch of the economic system is gradually becoming adjacent to the sphere of it technologies. Such a spread falls on all states of the world.

\subsection{Third trend: Digitalization of international security management}

New models of business are characterized by the innovations, the flexible and quickly developing companies. Startups in the field of information and digital technologies act as some of the main subjects to venture financing. In fact most of foreign and domestic businessmen in the field of ICT dream of repetition of success of the companies Uber, Zipcar, eBay, Kleiderei, Happy Tree and other companies which already took strong positions in the market of things and services for sharing. Technological frameworks for implementation of a business model in the field of consumption of "Personto-Person" are one of the most advanced developments on the market of modern ICT of technologies. At the same time there are at the innovation businessmen of the idea as about new an application of already known technological frameworks, and implementation of new technological capabilities (bigdata) [15].

In the conditions of rapid progress of the technologies providing globalization of economy and interrelation by means of the Internet of consumers of all countries of the world questions of culturological features and valuable reference points of economy of joint consumption rather sharply sound. Close attention in different aspects is paid to this direction which can be carried to social psychologically, many authors. So, the Italian authors M. Bernardi and D. Diamantini analyzed influence of these factors on economy of joint consumption by comparison of these forms of the organization of consumption in two cities - Milan (Italy) and Seoul (South Korea) [16]. Despite culturological differences between residents of these cities, researchers came to the general conclusion about need to develop the institutionalized mechanisms of cooperation in joint consumption at the level of the city. Carry institute of trust and institute of motivation to institutes which affect dynamics of processes in economy of joint consumption.

So, the main directions of digital transformation are:

- Digital transformation of economic sectors and crosssectoral transformation (digitization of physical assets, creation of added value through digital models, end-to-end processes, useful data; development of the data industry, development of digital platforms and ecosystems; creation of an environment for digital innovation)

- Digital transformation of the market of goods, services, capital and labor (cross-border e-Commerce; protection of intellectual property rights and consumer rights of the digital market; financial and technical innovations, joint mechanisms of risk, alternative and venture financing of digital innovations, digital skills and productivity; remote hiring and employment)

- Digital transformation of management processes and integration processes (modeling of processes and norms; mechanisms of development of initiatives and implementation of projects; integrated information system; interstate services; digital ecosystems)

- Development of digital infrastructure and security of digital processes (interoperability; networks of the latest generation $-4 \mathrm{G}$ and $5 \mathrm{G}$; critical digital infrastructure; security of digital processes and infrastructure).

The dynamics of the economy in the digital age are not only driven by new technology companies and enterprises: more than $75 \%$ of the value added comes from traditional industries through increased productivity through the use of the Internet and management of networks [17]. As the world experience shows, the digital economy is the driving 
force for accelerating global economic development, increasing production productivity, creating new markets and industries. It also opens up new opportunities for inclusive and sustainable growth. However, the acceleration of economic development is achieved by those countries and economic associations that systematically build the foundations and mechanisms of leadership in the digital economy.

\section{REFERENCES}

[1] WEF (2016) The 10 countries best prepared for the new digital economy. Retrieved from: https://www.weforum.org/agenda/2016/07/countriesbest-prepared-for-the-new-digital-economy

[2] Z.V. Prokopenko. The Essence of deformation processes in the system of transformational changes in the economy. Economic policy of economic growth. 2014, No. 11, p. 72.

[3] M. Porter International Competition: Country Competitive Advantage. Moscow, 1993. - 896 p. (In Russian).

[4] Digital Globalization: new era of global flows (2016), McKinsey. Retrieved from:

http://www.mckinsey.com/business-functions/digitalmckinsey/ourinsights/digital-globalization-the-new-eraof-global-flows

[5] Ch. Alexakis, V. Pappas Sectoral dynamics of financial contangion in Europe - The cases of recent crises episodes. Economic Modelling, 2018, 78, 37-54.

[6] Shaping the Digital Single Market (2017), European Commission. Retrieved from:

https://ec.europa.eu/digital-single-market/en/digitalsingle-market

[7] Developing the Digital Economy in Russia (2016), World Bank, Retrieved from: http://www.worldbank.org/en/events/2016/12/20/develo ping-the-digital-economy-in-russia-internationalseminar-1
[8] Ch. Alexakis, T. Ignatova, A. Polyanin Tests for sectorial market efficiency of the dynamics in Moscow Exchange. Revista ESPACIOS, 2019, Vol.40. № 10. P.17. Retrieved from: http://www.revistaespacios.com/a19v40n10/19401017.h tml

[9] V.V. Lipaev. Analysis and Reduction of Software Project Risks. JetInfo online, 2005, №1 (140).

[10] P. Braunerhjelm, M. Feldman. Cluster Genesis: Technology Based Industrial Development. Oxford: Oxford University Press, 2006. 353 p.

[11] A.A. Kuntsman. Transformation of internal and external business environment in the digital economy. Management of economic systems, 2016, 11 (93), pp.36-39.

[12] T.V. Stebenyeva, T.S. Larina, A.N. Petrov. The digital economy and its products: features social user experience. Modern scientific research and development, 2018, Vol.1, 5, pp. 589-597.

[13] T.R. Dillahunt, A.R. Malone. The promise of the sharing economy among disadvantaged communities. (2015) Conference on Human Factors in Computing Systems - Proceedings, 2015-April, pp. 2285-2294.

[14] T. Ignatova, G. Ovcharenko, N. Larkina, E. Filimontseva. Higher education impact onto development of innovative thinking of managers. Revista ESPACIOS. 2019, Vol.40, № 21, p.17. Retrieved from: https://revistaespacios.com/a19v40n21/19402117.html

[15] H. Heinrichs. Sharing economy: A potential new pathway to sustainability. GAIA, 2013, № 22 (4), pp. 228-231;

[16] M. Bernardi, D. Diamantini. Shaping the sharing city: An exploratory study on Seoul and Milan. Journal of Cleaner Production, 2018, № 203, pp. 30-42.

[17] M. Ersue, D. Romascanu, J. Schoenwaelder, A. Sehgal. Management of Networks with Constrained Devices: Use Cases. 2015, IETF Internet Draft. 